\title{
TAK-733, a Selective MEK Inhibitor, Enhances Voreloxin-induced Apoptosis in Myeloid Leukemia Cells
}

\author{
EWA JASEK-GAJDA, MARIUSZ GAJDA, MAŁGORZATA JASIŃSKA, JAN A. LITWIN and GRZEGORZ J. LIS \\ Department of Histology, Jagiellonian University Medical College, Krakow, Poland
}

\begin{abstract}
Background/Aim: MEK inhibitors are new promising anticancer drugs. The aim of this study was to investigate the effect of the combination treatment of voreloxin with the MEK inhibitor TAK-733 on HL60 myeloid leukemia cells. Materials and Methods: MAPK activity, cell viability, apoptosis, oxidative stress induction and AIF (apoptosisinducing factor) distribution were assessed in HL6O cells cultured with each drug alone or with both drugs. Results: TAK-733 alone at $5 \mu M$ significantly reduced MAPK activity and did not influence viability and apoptosis in HL60 cells. Voreloxin at concentration of 0.03-0.48 $\mu \mathrm{M}$ reduced cell viability and increased apoptosis rate. Incubation with both drugs caused further inhibition of cell viability and increased apoptosis associated with generation of reactive oxygen species (ROS) and nuclear translocation of AIF. Conclusion: Combination of TAK-733 and voreloxin can exert a synergistic anticancer effect in myeloid leukemia cells.
\end{abstract}

The Ras/Raf/mitogen-activated protein kinase (MEK)/ extracellular signal-regulated kinase (ERK) pathway is a key signaling cascade that regulates diverse cellular functions including cell proliferation, differentiation, survival and apoptosis. Dysregulated signaling through this pathway is often found in hematopoietic malignancies including acute myeloid leukemia (AML) (1-5). Recently, advances in the understanding of the biology of AML have led to new treatment strategies focused on targeting key effectors of the Ras/Raf/MEK/ERK pathway (6-8).

TAK-733 is a potent and selective MEK allosteric site inhibitor, which exerts anti-proliferative and pro-apoptotic effects in various cell lines and animal models for a wide range of malignancies including leukemias. In addition, several early-phase clinical trials involving TAK-733 as an

Correspondence to: Ewa Jasek-Gajda, Department of Histology, Jagiellonian University Medical College, Kopernika 7, PL-31034 Krakow, Poland. Tel: +48 124227027,e-mail: ewa.jasek@uj.edu.pl

Key Words: MEK inhibitors, TAK-733, voreloxin, apoptosis, ROS, AML. oral MEK inhibitor are now underway in cancer patients (913). Furthermore, TAK-733 has been found to enhance antitumor effects when used in combination with other chemotherapeutic agents in various cancer types (11). Moreover, in the same study the authors demonstrated antileukemic effects when TAK-733 was used in combination with bortezomib and AMD3100, the antagonist of the CXCR4 chemokine receptor.

Voreloxin is a first-in-class quinolone-based drug which intercalates DNA and inhibits topoisomerase II, resulting in replication-dependent, site-selective DNA damage, $\mathrm{G}_{2}$ arrest and apoptosis $(14,15)$. It has been investigated for the treatment of AML as a single agent and in combination with other targeted drugs (15-17). Unlike anthracyclines, which are also topoisomerase II inhibitors, voreloxin has demonstrated only limited cardiotoxicity, what makes it an attractive therapeutic compound for cancer therapy $(14,18)$.

In search of a more effective approach for the treatment of AML, new strategies have been recently proposed, including a combination of drugs targeting two different signaling pathways $(7,19,20)$.

To our knowledge, the potential efficacy of the combination of MEK inhibitors and voreloxin in the treatment of AML is unknown. We, therefore, investigated the effect of TAK-733 combined with voreloxin on HL60 myeloid leukemia cells.

\section{Materials and Methods}

Drugs. TAK-733 and voreloxin were purchased form Selleck Chemicals (Selleckchem, Houston, TX, USA). Stock solutions of drugs were aliquoted and kept frozen at $-20^{\circ} \mathrm{C}$.

Cell culture. HL60 cells (Sigma-Aldrich, St Louis, CA, USA) were maintained in RPMI-1640 GlutaMax medium supplemented with $10 \%$ fetal bovine serum (FBS) containing $100 \mathrm{U} / \mathrm{ml}$ penicillin, and $100 \mu \mathrm{g} / \mathrm{ml}$ streptomycin (all reagents from Life Technologies, Carlsbad, CA, USA). Cells were cultured at $37^{\circ} \mathrm{C}$ in a humidified $5 \% \mathrm{CO}_{2}$ atmosphere.

Cell viability assay. The trypan blue exclusion method was used to assess cell viability. HL60 cells were incubated with trypan blue solution ( $0.2 \%$ in PBS; Sigma) and the viability was estimated using 
a hemocytometer. Cell viability was expressed as the percentage of the control $(100 \%)$.

MAPK activity assay. The Muse MAPK Activation Dual Detection Kit (Merck Millipore, Billerica, MA, USA), including phosphospecific anti-phospho-ERK1/2 (Thr202/Tyr204, Thr185/Tyr187)Phycoerythrin and anti-ERK1/2-PECy5-conjugated antibodies, was used to measure MAPK activity in HL60 cells. Briefly, $5 \times 10^{5}$ cells were washed with PBS and fixed in Fixation buffer for 5 min on ice. Then, the cells were treated with permeabilization buffer for 5 min on ice and incubated with a solution of antibodies for $30 \mathrm{~min}$ at room temperature in the dark. MAPK activity was determined as the percentage of phosphorylated MAPK to the total MAPK expression in cell population using Muse Cell Analyzer and Muse analysis software.

Apoptosis assay. Apoptotic cells were analyzed using Muse Annexin $\mathrm{V}$ and Dead Cell Kit (Merck Millipore) according to a previously described protocol (21). This assay utilizes Annexin V to detect phosphatidylserine on the external membrane leaflet of apoptotic cells and dead cell marker, 7-AAD, as an indicator of cell membrane integrity. Briefly, $5 \times 10^{5}$ cells were resuspended in culture medium containing 1\% FBS and incubated with Muse Annexin V and Dead Cell Reagent for $20 \mathrm{~min}$ at room temperature in the dark. Cells were quantified using Muse Cell Analyzer and Muse analysis software.

Oxidative stress assay. Cell population undergoing oxidative stress was measured using Muse ${ }^{\mathrm{TM}}$ Oxidative Stress kit (Merck Millipore) according to manufacturer's instructions. Briefly, $5 \times 10^{5}$ cells were resuspended in Muse $^{\mathrm{TM}}$ Oxidative Stress working solution containing dihydroethidium (DHE) and incubated for $30 \mathrm{~min}$ at $37^{\circ} \mathrm{C}$. DHE is cell permeable and reacts with superoxide anions, thus undergoing oxidation upon binding to DNA. Cells were quantified using Muse Cell Analyzer and the relative percentage of ROS positive and ROS negative cells was estimated by Muse analysis software.

Subcellular distribution of AIF analyzed by immunostaining and confocal microscopy. Control and treated cells were collected and cytospin smears were prepared. Cells were then fixed with $4 \%$ buffered paraformaldehyde for $5 \mathrm{~min}$ at room temperature. Following a triple rinse with PBS, cells were pre-incubated in primary antibody dilutor (PAD) comprising $10 \%$ normal goat serum, $0.1 \%$ bovine serum albumin, $0.1 \%$ Triton $\mathrm{X}-100,0.05 \%$ thimerosal and $0.01 \% \mathrm{NaN} 3$ (all reagents from Sigma) for $30 \mathrm{~min}$ at room temperature. Primary rabbit anti-AIF polyclonal antibody (Santa Cruz Biotechnology, CA, USA; diluted 1:200 in PAD) was applied for an overnight incubation at room temperature. Then, cells were washed three times with PBS and incubated with secondary Cy3-conjugated goat anti-rabbit IgG antibody (Jackson ImmunoResearch, West Grove, PA, USA; diluted 1:500 in PAD) for $1 \mathrm{~h}$ in the dark. Cells were rinsed three times with PBS, stained with Hoechst 33342 (Sigma; $2.5 \mu \mathrm{g} / \mathrm{ml}$ in PBS) for $5 \mathrm{~min}$ and mounted in glycerol/PBS (2:1). Images of stained cells were obtained by confocal microscopy (Olympus FluoView 1200 on inverted stand IX83; Olympus, Tokyo, Japan). Sixty-times magnification immersion objective $(\mathrm{NA}=1.4)$ was used and heliumneonium laser $(453 \mathrm{~nm})$ and diode laser $(405 \mathrm{~nm})$ were applied to excite red (Cy3) and blue (Hoechst) fluorescence, respectively. The stacks of optical sections were acquired and further processed with Olympus FV10 software.
Statistical analysis. The results are expressed as mean \pm standard deviation (SD) of five independent experiments. Statistical analysis was performed by Mann-Whitney test. $p<0.05$ was considered statistically significant. Data were analyzed using the Prism 5.0 software (GraphPad, La Jolla, CA, USA).

\section{Results}

Effect of TAK-733 on cell viability and MAPK activity. HL60 cells were treated with increasing concentrations of TAK-733 (1.25 to $20 \mu \mathrm{M})$ for $24 \mathrm{~h}$. Cell viability was decreased in a dose-dependent manner starting from $2.5 \mu \mathrm{M}$ (Figure 1A). MAPK activity was also significantly reduced and reached the lowest relative level at $20 \mu \mathrm{M}(13.72 \% \pm 3.97 \%)$. Concentration of $5 \mu \mathrm{M}$ TAK-733 was chosen for further studies, as the highest concentration having a relatively low toxic effect on cells ( $\sim 15 \%$ decrease in viability). At that concentration MAPK activity was reduced to approximately $80 \%$ (Figure $1 \mathrm{~B}$ and $\mathrm{C}$ ).

Effect of voreloxin on cell viability and apoptosis. HL60 cells were exposed to increasing concentrations of voreloxin $(0.03 \mu \mathrm{M}$ to $0.48 \mu \mathrm{M}$ ) for $24 \mathrm{~h}$. The cell viability was decreased in a dosedependent manner (Figure 2A). The total apoptotic rate (early and late apoptosis) increased from $6.83 \% \pm 1.1 \%$ to $38.18 \% \pm 5.78 \%$ at the highest concentration (Figure 2B and C).

Effects of combined TAK-733 and voreloxin treatment on MAPK activity. HL60 cells were first treated with $5 \mu \mathrm{M}$ TAK-733 for $24 \mathrm{~h}$ and then with $0.24 \mu \mathrm{M}$ voreloxin for another $24 \mathrm{~h}$. The dose of voreloxin was selected to cause approximately $20 \%$ reduction in cell viability. Voreloxin alone had no significant effect on MAPK activity compared to control cells. Combined treatment with TAK-733 followed by voreloxin showed exactly the same effect (Figure $3 \mathrm{~A}$ and B).

Effect of combined TAK-733 and voreloxin treatment on ROS production in HL60 cells. TAK-733 and voreloxin alone had no significant effect on the oxidative stress induction in cells compared to untreated control. A significant increase in ROS positive cells $(\sim 25 \%$ relative to the control) was observed only after they were treated with both TAK-733 and voreloxin (Figure 4A and B).

Effects of combined TAK-733 and voreloxin treatment on cell apoptosis. TAK-733 alone did not significantly influence apoptosis in HL60 cells, whereas voreloxin-induced apoptosis was markedly potentiated after a combined treatment with TAK-733 and the percentages of apoptotic cells were about 3-fold higher compared to voreloxin alone (Figure 5A and B).

Nuclear translocation of AIF determined by confocal microscopy. In untreated control cells, AIF was found to be mainly distributed in the cytoplasm, showing punctuated 


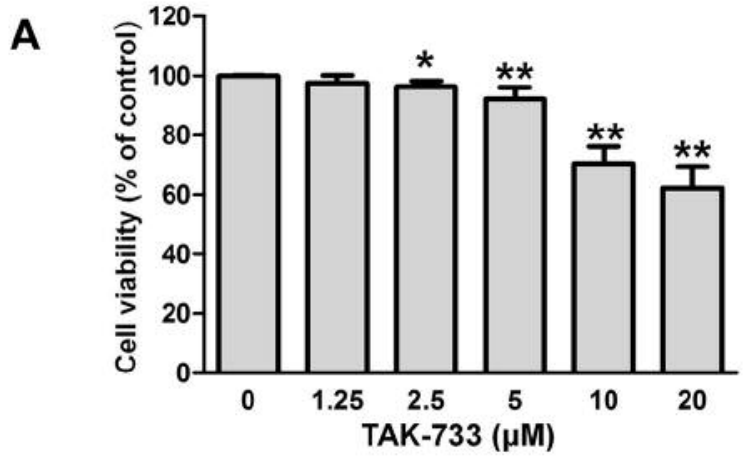

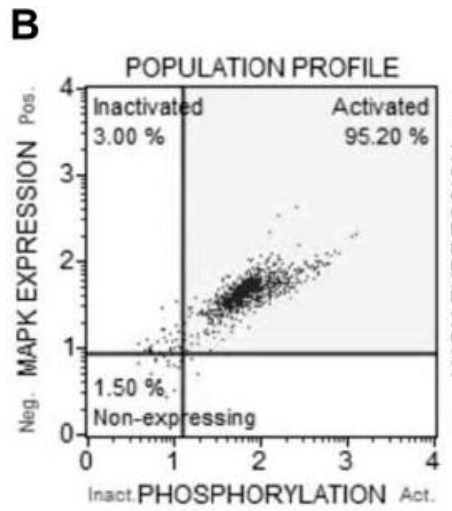

Control

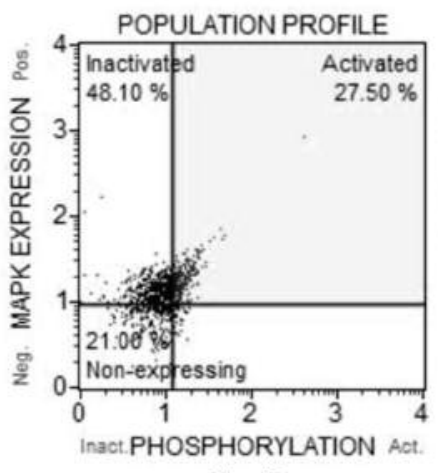

$5 \mu \mathrm{M}$

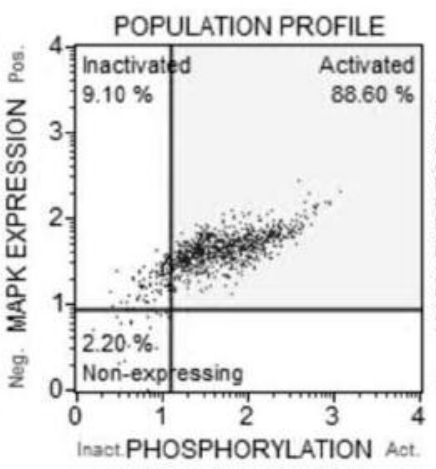

$1.25 \mu \mathrm{M}$

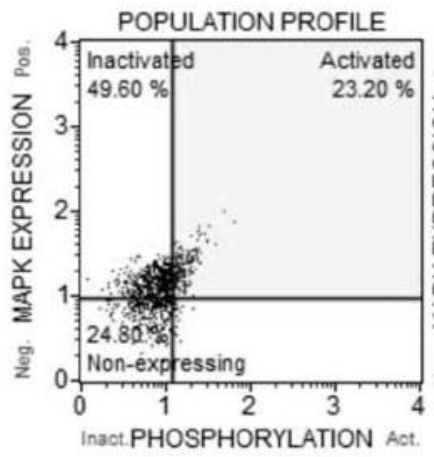

$10 \mu \mathrm{M}$

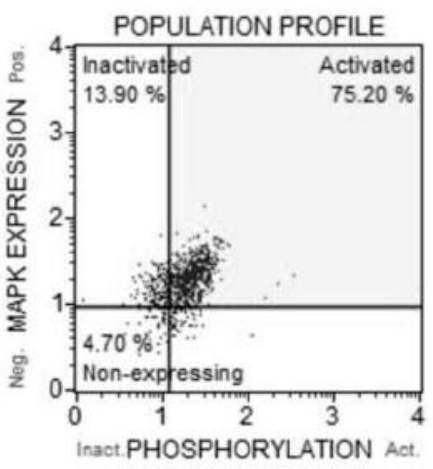

$2.5 \mu \mathrm{M}$

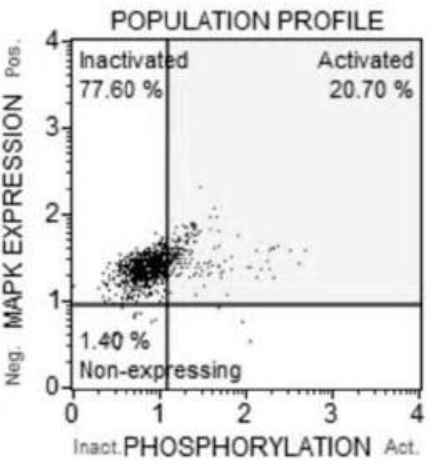

$20 \mu \mathrm{M}$

C

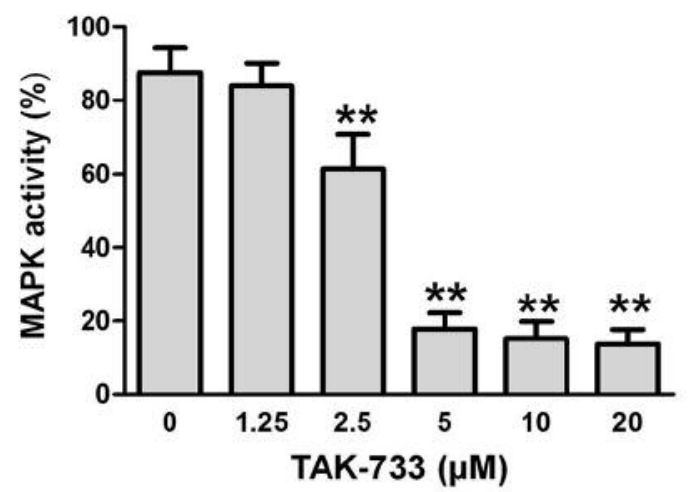

Figure 1. Effect of TAK-733 on cell viability (A) and MAPK activity ( $B$ and $C$ ) in HL60 cells. Representative dot plots and graph of MAPK activity assay ( $B$ and $C$ ). TAK-733 decreased cell viability and lowered MAPK activity in a dose-dependent manner. Each value is the mean $\pm S D$ of five experiments. Significantly different from untreated (control) cells: $*(p<0.05), * *(p<0.01)$. 


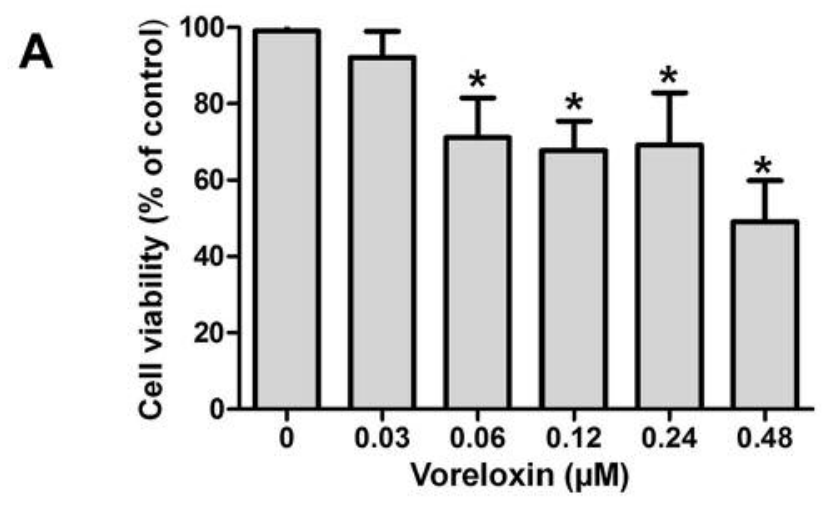

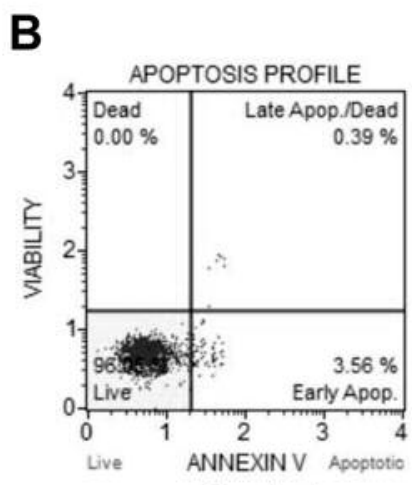

Control

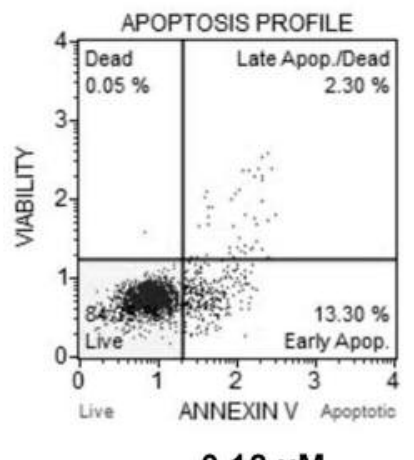

$0.12 \mu \mathrm{M}$

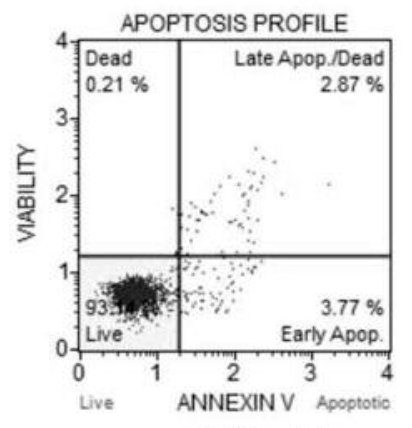

$0.03 \mu \mathrm{M}$

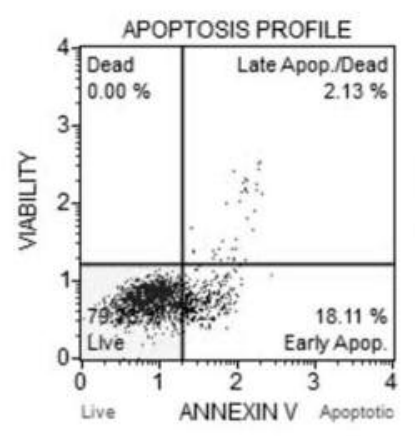

$0.24 \mu \mathrm{M}$

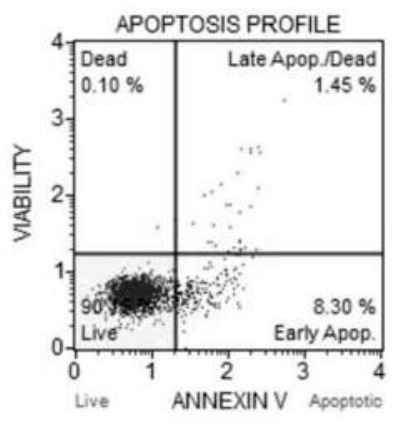

$0.06 \mu \mathrm{M}$

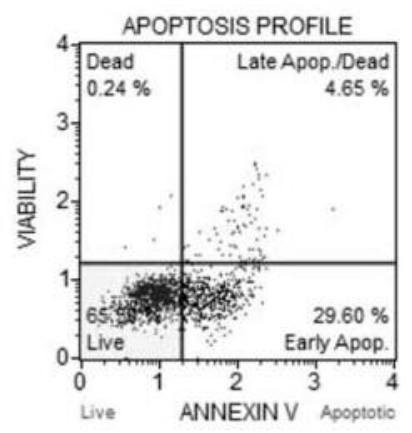

$0.48 \mu \mathrm{M}$

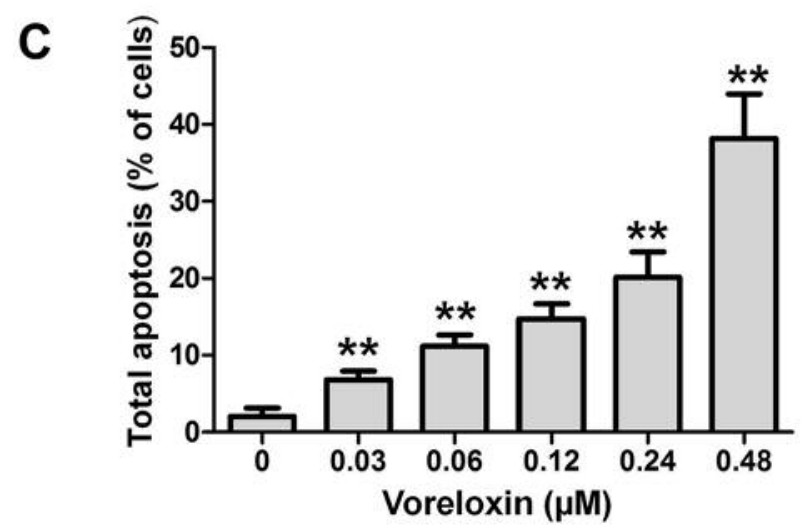

Figure 2. Effect of voreloxin on cell viability (A) and apoptosis (B and C) of HL60 cells. Representative dot plots of Annexin V/7-AAD apoptotic assay $(B)$ and a graph showing the percentage of apoptotic cells $(C)$. Voreloxin decreased cell viability and increased apoptosis in a dose-dependent manner. Each value is the mean \pm SD of five experiments. Significantly different from untreated $($ control $)$ cells: $*(p<0.05), * *(p<0.01)$. 

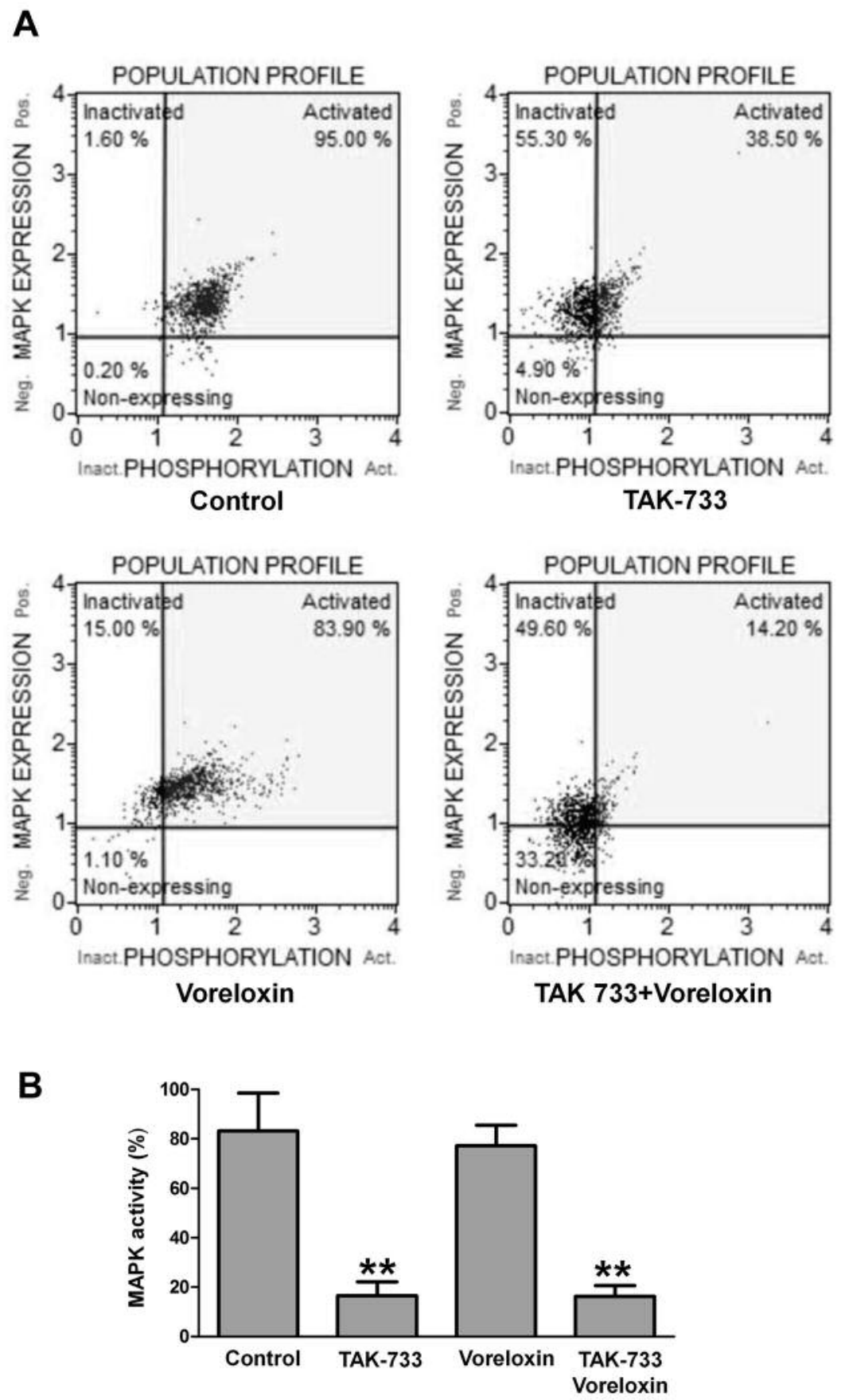

Figure 3. Effect of TAK-733 and voreloxin on MAPK activity in HL60 cells. Representative dot plots and graph of MAPK activity assay (A and B). Each value is the mean $\pm S D$ of 5 experiments. **Significantly different from untreated (control) cells $(p<0.01)$.

immunofluorescence pattern. Cells treated with TAK-733 or voreloxin alone showed predominantly cytoplasmic location of AIF, although very weak immunostaining was observed also in the nuclei. Translocation of AIF to the nuclei of HL60 cells occurred after combined treatment with TAK-733 and voreloxin, with only a weak signal remaining in the cytoplasm (Figure 6).

\section{Discussion}

Combination of drugs which target Ras/Raf/Mek/Erk signaling pathway with traditional chemotherapeutics seems to be an encouraging approach to anticancer treatment. In the present study, preincubation of AML cells with MEK 

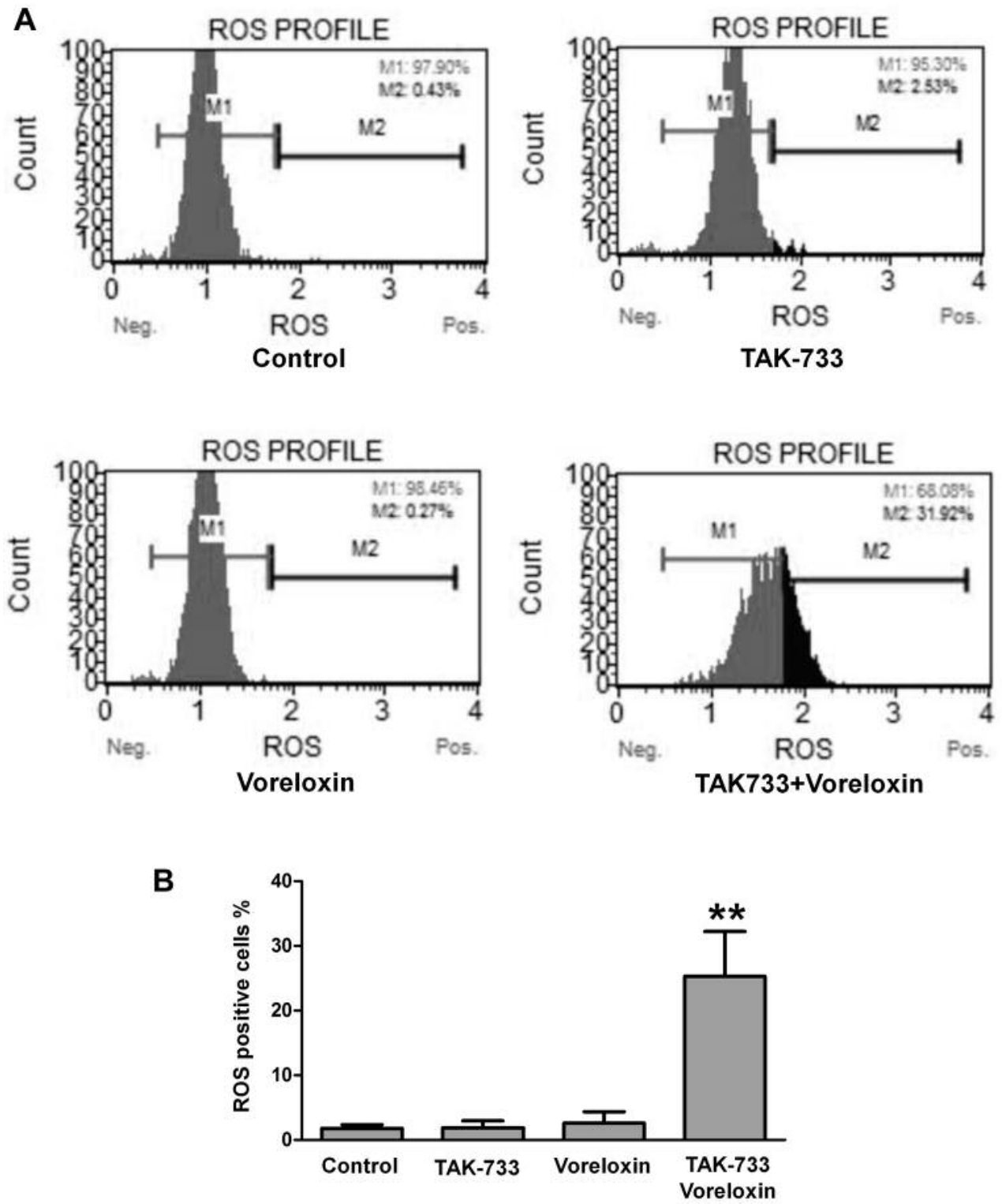

Figure 4. Effect of TAK-733 and voreloxin on ROS production in HL60 cells. Representative histograms of ROS negative (M1) and ROS positive (M2) cells (A) and a graph showing the percentage of ROS positive cells $(B)$. Each value is the mean $\pm S D$ of 5 experiments. **Significantly different from untreated (control) cells $(p<0.01)$.

inhibitor TAK-733 for $24 \mathrm{~h}$ significantly potentiated voreloxin-induced apoptosis. It has been shown that constitutive MAPK phosphorylation is responsible for a poor response to chemotherapy and shorter survival in AML patients (22). In our study, untreated HL60 cells displayed a high basal level of MAPK activity. According to the literature, MAPK is strongly activated in AML cell lines including HL60 cells $(22,23)$. We have found that TAK-733 significantly reduced MAPK expression in HL60 cells and this effect was observed at a non-toxic concentration.
Similarly, another study has reported that TAK-733 is highly potent in suppressing MAPK activity in H929 multiple myeloma cells (11).

Apoptosis is characterized by a series of biochemical and morphological changes and one of the most significant events in apoptosis is mitochondrial dysfunction and ROS overproduction (24). As has mentioned earlier, high levels of reactive oxygen species play an important role in cancer therapy by inducing cell death through apoptosis (25). It was previously shown that current standard AML chemotherapy 
A
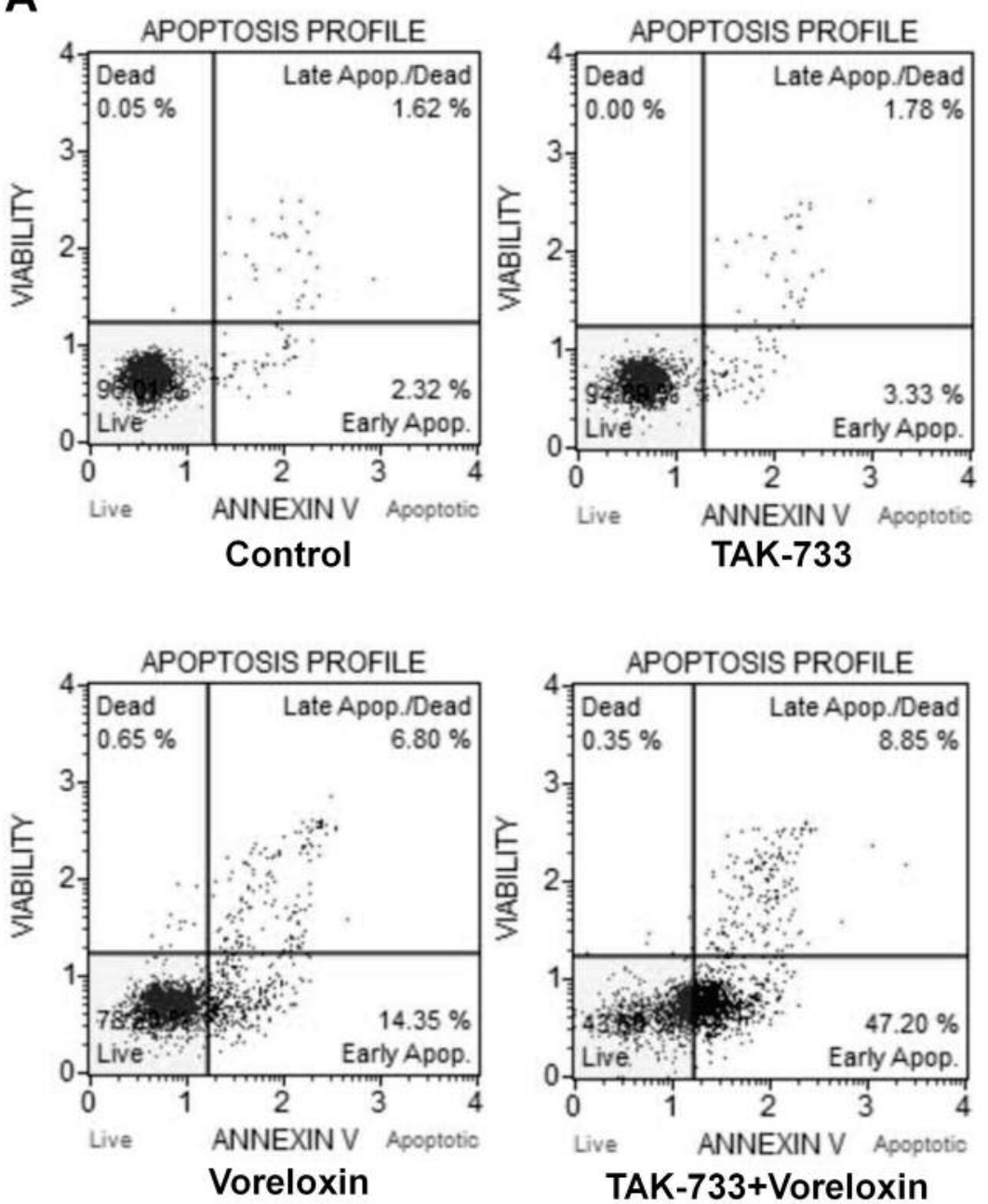

TAK-733+Voreloxin

B

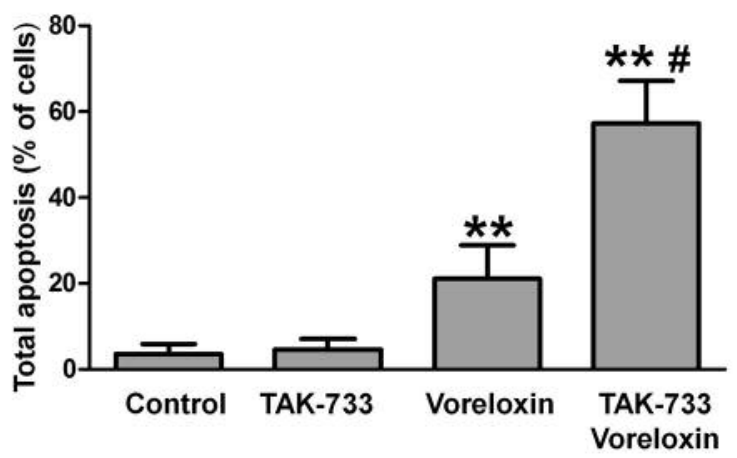

Figure 5. Effect of PJ34 and vorinostat on apoptosis in HL60 cells. Representative dot plots of Annexin V/7-AAD apoptotic assay (A) and a graph showing the percentage of apoptotic cells $(B)$. Each value is the mean $\pm S D$ of five experiments. Significantly different from untreated (control) cells: $*(p<0.05), * *(p<0.01)$. " significantly different from voreloxin-treated cells $(p<0.01)$.

induces an increase in ROS level in AML cells as part of its mechanism of cytotoxic action (26). We observed that apoptotic cell death induced by combinatorial treatment with both TAK-733 and voreloxin is related to enhanced ROS production. Interestingly, TAK-733 and voreloxin alone did not induce significant increase in ROS levels. Compared with other topoisomerase II inhibitors doxorubicin and mitoxantrone, voreloxin is less reactive quinolone-based 


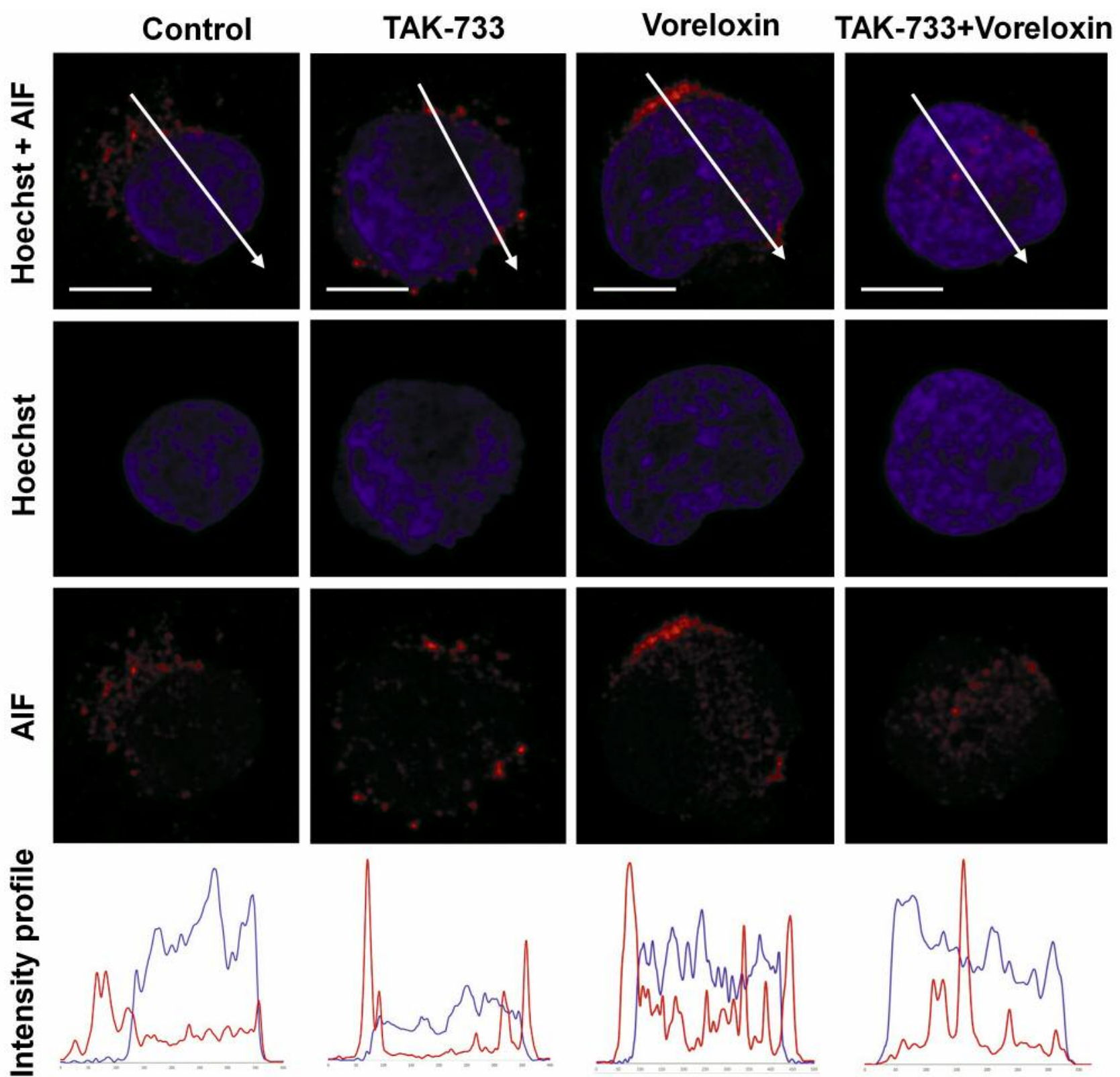

Figure 6. Representative images of HL60 cells: untreated (control) and treated with TAK-733 or/and voreloxin. Cells were immunostained for AIF (red fluorescence) and the nuclei were stained blue with Hoechst 33342. The lowermost row presents plots of fluorescence intensities for AIF and Hoechst along the lines indicated in the uppermost row images. Bar $=10 \mu \mathrm{m}$.

structure, generating limited ROS levels $(27,28)$. It should be noted that cell response to treatment with combination of drugs can depend upon a variety of factors. In some cases, potentiation of another drug action or sensitization of cells to a drug is induced by ROS generation $(29,30)$. Although cancer cells can regulate ROS levels by enhancing endogenous antioxidant mechanisms, they may be more prone to accumulation of ROS than normal cells.
Consequently, it has been suggested that oxidative stress increased by exogenous ROS generating agents has an effect of selectively killing cancer cells without affecting normal cells $(31,32)$. Moreover, the enhanced ROS production after combined TAK-733 and voreloxin treatment might also contribute to AIF nuclear translocation. We therefore evaluated activation of AIF after treatment with TAK-733 and voreloxin. Confocal microscopy has revealed that 
translocation of AIF to the nuclei of HL60 cells was detected only after combined treatment with both agents. It has been reported that AIF-mediated apoptosis is a caspaseindependent event. AIF is released from mitochondria upon death stimuli, subsequently translocates into the nucleus, and causes nuclear condensation (33-35). As demonstrated in other studies ROS and AIF are mostly associated with caspase-independent pathway, moreover the increase of intracellular ROS is required for AIF translocation and cell death $(36,37)$.

In conclusion, TAK-733 and voreloxin combination resulted in a synergistic effect through enhancing ROS generation in HL60 cells, thereby inducing an increase in AIF- induced apoptosis. We showed that MEK inhibition by TAK-733 can sensitize HL60 cells to voreloxin. These data provide a rationale for drug combination targeting of MEK pathways for the treatment of AML.

\section{Conflicts of Interest}

There are no conflicts of interest regarding this study.

\section{Acknowledgements}

This study was supported by statutory funds K/ZDS/007917 from the Jagiellonian University Medical College to E.J.G.

\section{References}

1 Chung E and Kondo M: Role of Ras/Raf/MEK/ERK signaling in physiological hematopoiesis and leukemia development. Immunol Res 49: 248-268, 2011.

2 Rawendra RD, Lin PY, Chang CD, Hsu JL, Huang TC and Shih WL: Potentiation of acute promyelocytic leukemia cell differentiation and prevention of leukemia development in mice by oleanolic acid. Anticancer Res 35: 6583-6590, 2015.

3 Huang X, Schwind S, Santhanam R, Eisfeld AK, Chiang CL, Lankenau M, Yu B, Hoellerbauer P, Jin Y, Tarighat SS, Khalife J, Walker A, Perrotti D, Bloomfield CD, Wang H, Lee RJ, Lee LJ and Marcucci G: Targeting the RAS/MAPK pathway with miR-181a in acute myeloid leukemia. Oncotarget 7: 5927359286, 2016.

4 Tyner JW, Erickson H, Deininger MW, Willis SG, Eide CA, Levine RL, Heinrich MC, Gattermann N, Gilliland DG, Druker BJ and Loriaux MM: High-throughput sequencing screen reveals novel, transforming RAS mutations in myeloid leukemia patients. Blood 113: 1749-1755, 2009.

5 Blalock WL, Moye PW, Chang F, Pearce M, Steelman LS, McMahon M and McCubrey JA: Combined effects of aberrant MEK1 activity and BCL2 overexpression on relieving the cytokine dependency of human and murine hematopoietic cells Leukemia 14: 1080-1096, 2000.

6 Steelman LS, Franklin RA, Abrams SL, Chappell W, Kempf CR, Bäsecke J, Stivala F, Donia M, Fagone P, Nicoletti F, Libra M, Ruvolo P, Ruvolo V, Evangelisti C, Martelli AM and McCubrey JA: Roles of the Ras/Raf/MEK/ERK pathway in leukemia therapy. Leukemia 25: 1080-1094, 2011.
7 Kerstjens M, Driessen EM, Willekes M, Pinhanços SS, Schneider P, Pieters R and Stam RW: MEK inhibition is a promising therapeutic strategy for MLL-rearranged infant acute lymphoblastic leukemia patients carrying RAS mutations. Oncotarget 8: 14835-14846, 2017.

8 Knight $\mathrm{T}$ and Irving JA: Ras/Raf/MEK/ERK pathway activation in childhood acute lymphoblastic leukemia and its therapeutic targeting. Front Oncol 4: 160, 2014.

9 Dong Q, Dougan DR, Gong X, Halkowycz P, Jin B, Kanouni T, O'Connell SM, Scorah N, Shi L, Wallace MB and Zhou F: Discovery of TAK-733, a potent and selective MEK allosteric site inhibitor for the treatment of cancer. Bioorg Med Chem Lett 21: 1315-1319, 2011.

10 Lieu CH, Klauck PJ, Henthorn PK, Tentler JJ, Tan AC, Spreafico A, Selby HM, Britt BC, Bagby SM, Arcaroli JJ, Messersmith W, Pitts TM and Eckhardt SG: Antitumor activity of a potent MEK inhibitor, TAK-733, against colorectal cancer cell lines and patient-derived xenografts. Oncotarget 6: 34561-34572, 2015.

11 de la Puente P, Muz B, Jin A, Azab F, Luderer M, Salama NN and Azab AK: MEK inhibitor, TAK-733 reduces proliferation, affects cell cycle and apoptosis, and synergizes with other targeted therapies in multiple myeloma. Blood Cancer J 6: e399, 2016.

12 Micel LN, Tentler JJ, Tan AC, Selby HM, Brunkow KL, Robertson KM, Davis SL, Klauck PJ, Pitts TM, Gangolli E, Fabrey R, O'Connell SM, Vincent PW and Eckhardt SG: Antitumor activity of the MEK inhibitor TAK-733 against melanoma cell lines and patient-derived tumor explants. Mol Cancer Ther 14: 317-325, 2015.

13 Adjei AA, LoRusso P, Ribas A, Sosman JA, Pavlick A, Dy GK, Zhou X, Gangolli E, Kneissl M, Faucette S, Neuwirth R and Bózon V: A phase I dose-escalation study of TAK-733, an investigational oral MEK inhibitor, in patients with advanced solid tumors. Invest New Drugs 35: 47-58, 2017.

14 Hoch U, Lynch J, Sato Y, Kashimoto S, Kajikawa F, Furutani Y and Silverman JA: Voreloxin, formerly SNS-595, has potent activity against a broad panel of cancer cell lines and in vivo tumor models. Cancer Chemother Pharmacol 64: 53-65, 2009.

15 Walsby EJ, Coles SJ, Knapper S and Burnett AK: The topoisomerase II inhibitor voreloxin causes cell cycle arrest and apoptosis in myeloid leukemia cells and acts in synergy with cytarabine. Haematologica 93: 393-399, 2011.

16 Fathi AT and Karp JE: New agents in acute myeloid leukemia: beyond cytarabine and anthracyclines. Curr Oncol Rep 11: 346$352,2009$.

17 Sayar $\mathrm{H}$ and Bashardoust P: Therapies for acute myeloid leukemia: vosaroxin. Onco Targets Ther 10: 3957-3963, 2017.

18 McGowan JV, Chung R, Maulik A, Piotrowska I, Walker JM and Yellon DM: Anthracycline chemotherapy and cardiotoxicity. Cardiovasc Drugs Ther 31: 63-75, 2017.

19 Wander SA, Levis MJ and Fathi AT: The evolving role of FLT3 inhibitors in acute myeloid leukemia: quizartinib and beyond. Ther Adv Hematol 5: 65-77, 2014.

20 Ouchida AT, Li Y, Geng J, Najafov A, Ofengeim D, Sun X and Yu Q: Yuan J Synergistic effect of a novel autophagy inhibitor and quizartinib enhances cancer cell death. Cell Death Dis 9: 138, 2018.

21 Jasek E, Gajda M, Lis GJ, Jasińska $M$ and Litwin JA: Combinatorial effects of PARP inhibitor PJ34 and histone deacetylase inhibitor vorinostat on leukemia cel lines. Anticancer Res 34: 1849-1856, 2014. 
22 Milella M, Kornblau SM, Estrov Z, Carter BZ, Lapillonne H, Harris D, Konopleva M, Zhao S, Estey E and Andreeff M: Therapeutic targeting of the MEK/MAPK signal transduction module in acute myeloid leukemia. J Clin Invest 108: 851-859, 2001.

23 Lehman JA, Paul CC, Baumann MA and Gómez-Cambronero J: MAP kinase upregulation after hematopoietic differentiation: role of chemotaxis. Am J Physiol Cell Physiol 280: 183-191, 2001.

24 Fruehauf JP and Meyskens FL Jr.: Reactive oxygen species: a breath of life or death? Clin Cancer Res 13: 789-794, 2007.

25 Chen P, Luo X, Nie P, Wu B, Xu W, Shi X, Chang H, Li B, Yu $\mathrm{X}$ and Zou Z: CQ synergistically sensitizes human colorectal cancer cells to $\mathrm{SN}-38 / \mathrm{CPT}-11$ through lysosomal and mitochondrial apoptotic pathway via p53-ROS cross-talk. Free Radic Biol Med 104: 280-297, 2017.

26 Heasman SA, Zaitseva L, Bowles KM, Rushworth SA and Macewan DJ: Protection of acute myeloid leukaemia cells from apoptosis induced by front-line chemotherapeutics is mediated by haem oxygenase-1. Oncotarget 2: 658-668, 2011.

27 Mitscher LA: Bacterial topoisomerase inhibitors: quinolone and pyridone antibacterial agents. Chem Rev 105: 559-592, 2005.

28 Hawtin RE, Stockett DE, Byl JA, McDowell RS, Nguyen T, Arkin MR, Conroy A, Yang W, Osheroff $\mathrm{N}$ and Fox JA: Voreloxin is an anticancer quinolone derivative that intercalates DNA and poisons topoisomerase II. PLoS One 5: e10186, 2010.

29 Gao S, Mobley A, Miller C, Boklan J and Chandra J: Potentiation of reactive oxygen species is a marker for synergistic cytotoxicity of MS-275 and 5-azacytidine in leukemic cells. Leuk Res 32: 771-780, 2008.

30 Wang MJ, Liu S, Liu Y and Zheng D: Actinomycin D enhances TRAIL-induced caspase-dependent and -independent apoptosis in SH-SY5Y neuroblastoma cells. Neurosci Res 59: 40-46, 2007.

31 Georgieva E, Ivanova D, Zhelev Z, Bakalova R, Gulubova M and Aoki I: Mitochondrial dysfunction and redox imbalance as a diagnostic marker of "free radical diseases". Anticancer Res 37: 5373-5381, 2017.
32 Liu J and Wang Z: Increased Oxidative Stress as a Selective Anticancer Therapy: Oxid Med Cell Longev 2015: 294303, 2015.

33 Susin SA, Lorenzo HK, Zamzami N, Marzo I, Snow BE, Brothers GM, Mangion J, Jacotot E, Costantini P, Loeffler M, Larochette N, Goodlett DR, Aebersold R, Siderovski DP, Penninger JM and Kroemer G: Molecular characterization of mitochondrial apoptosis-inducing factor. Nature 397: 441-446, 1999.

34 Joza N, Susin SA, Daugas E, Stanford WL, Cho SK, Li CY, Sasaki T, Elia AJ, Cheng HY, Ravagnan L, Ferri KF, Zamzami N, Wakeham A, Hakem R, Yoshida H, Kong YY, Mak TW, Zuniga-Pflucker JC, Kroemer G and Penninger JM: Essential role of the mitochondrial apoptosis-inducing factor in programmed cell death. Nature 410: 549-554, 2001.

35 Otera H, Ohsakaya S, Nagaura Z, Ishihara N and Mihara K: Export of mitochondrial AIF in response to proapoptotic stimuli depends on processing at the intermembrane space. EMBO J 24: 1375-1386, 2005.

36 Zhou H, Xu M, Gao Y, Deng Z, Cao H, Zhang W, Wang Q, Zhang B, Song G, Zhan Y and Hu T: Matrine induces caspaseindependent program cell death in hepatocellular carcinoma through bid-mediated nuclear translocation of apoptosis inducing factor. Mol Cancer 13: 59, 2014.

37 Kang YH, Yi MJ, Kim MJ, Park MT, Bae S, Kang CM, Cho CK, Park IC, Park MJ, Rhee CH, Hong SI, Chung HY, Lee YS and Lee SJ: Caspase-independent cell death by arsenic trioxide in human cervical cancer cells: reactive oxygen species-mediated poly(ADPribose) polymerase-1 activation signals apoptosis-inducing factor release from mitochondria. Cancer Res 64: 8960-8967, 2004.

Received September 25, 2018

Revised October 8, 2018

Accepted October 10, 2018 